\title{
Price spread in Different Marketing Channels of Onion in Bhavnagar District of Gujarat, India
}

\author{
G.K. Kantariya ${ }^{1 *}$, N.J. Ardeshna ${ }^{1}$, K.M. Vasavada ${ }^{1}$ and V.M. Thumar $^{2}$ \\ ${ }^{1}$ Department of Agricultural Economics, Junagadh Agricultural University, Junagadh \\ (Gujarat), India \\ ${ }^{2}$ Directorate of Rsearch, Navsari Agricultural University, Navsari (Gujarat), India \\ *Corresponding author
}

\begin{tabular}{|c|}
\hline Keywords \\
\hline $\begin{array}{l}\text { Onion, Marketing } \\
\text { cost and margin, } \\
\text { price spread and } \\
\text { Garrett's ranking }\end{array}$ \\
\hline Article Info \\
\hline $\begin{array}{l}\text { Accepted: } \\
\text { 04 September } 2018 \\
\text { Available Online: } \\
10 \text { October } 2018\end{array}$ \\
\hline
\end{tabular}

\section{A B S T R A C T}

The present investigation was undertaken with a view to study the marketing cost, marketing margin, price spread and constraints marketing of onion in Bhavnagar district of Gujarat. The marketing cost, margin and price spread of different identified marketing channel and constraints of marketing were analysed. It is observed that the marketable surplus on sample farms was 98.54 per cent of total onion production. The highest quantum of production $(57.89 \%$ ) was sold through commission agent, followed by primary wholesalers. The onion growers paid the highest average total marketing cost of Rs. 57.27 per quintal of onion sold through commission agent followed by secondary wholesaler. On an average about $54.80,19.39,11.10,9.41$ and 5.31 per cent of total quantity of onion sold through Channel-IV (Producer - Commission agent - Primary Wholesaler - Processor), Channel-V (Producer - Primary wholesaler - Secondary wholesaler - Processor), ChannelII (Producer - Commission agent - Primary wholesaler - Retailer - Consumer), Channel-I (Producer - Local Merchant - Consumer) and Channel-III (Producer - Primary wholesaler Retailer - Consumer), respectively. The producers got the highest net price per quintal in the Channel-IV. The marketing cost per quintal was the highest in the Channel-II (Rs. 319.00) while the marketing margin was the highest in Channel-I (Rs. 136.31) followed by Channel-V. The producer's share in consumer's rupee per quintal was the highest in Channel-I while marketing efficiency was the highest in Channel-I. Majority of the onion cultivators felt the problem of fluctuation in market prices followed by lack of storage and transportation facilities.

\section{Introduction}

Onion is one of the important horticultural crop enhance the farmers economy occupied 13.06 lakh hectares area under cultivation which produce about 224.27 lakh metric tonnes in 2016-17 (Anon., 2017 a). Moreover, area, production and yield of onion crop grown found quite instable due to fluctuation in prices and several other factors. Gujarat is the leading state with 0.51 lakh hectares of area under onion cultivation with production of 12.90 lakh tonnes with the highest productivity of 26.54 tonnes/ha in year 201617 (Anon., 2017 b). It is also reported that the annual area, production and productivity of 
onion increased at the rate of $6.50,9.96$ and 0.68 per cent, respectively in Gujarat during 1990-91 to 2006-07 (Ardeshna and Shiyani, 2014). The region of Saurashtra alone contributes area of 0.48 lakh hectares in onion cultivation and 12.19 lakh tonnes of onion production in year 2016-17. The Bhavnagar districts of Saurashtra region alone contribute 67.82 per cent in terms of area and 69.88 per cent in terms of production of onion during the year 2016-17(Anon., 2017b).

The efficient marketing of onion is one of the important factors determining the profitability of the crop due to perishability, bulkiness and seasonal nature of onion. Therefore, considering the crucial role of marketing system and its efficiency, the present investigation was carried out to identify different marketing channels along with marketing cost and margins and to identify various constraints in onion marketing in the study area.

\section{Materials and Methods}

Bhavnagar district was selected purposively, as it collectively covers 67.82 per cent area of onion cultivation with 69.88 per cent share in production of onion in the state in the year 2016-17.A proportional sample of 120 producers comprised of 20 respondents was selected for study from each three onion cultivation concentrated villages of Mahuva and Talaja talukas of Bhavnagar district classified in to four different farm size groups viz., Marginal (up to 1.00 hectare), Small (>1.00 to 2.00 hectares), Medium (>2.00 to 4.00 hectares) and Large (above 4.00 hectares). For the study of marketing aspects of onion, the Bhavnagar and Mahuva regulated markets were selected on the basis of quantity of onion arrived in the market. A sample of eight respondents from each of different marketing functionaries like local merchants, primary wholesaler, secondary wholesaler, commission agent and retailer was randomly selected from both the selected markets to study various marketing aspects. Thus, in addition to 120 producers a total sample of 80 respondents from different marketing functionaries was selected for the study. The required primary data on various aspects of marketing was collected through interview schedule from the selected respondents.

\section{Marketing analysis}

The producer's share, marketing costs and margins of middleman in marketing of onion worked out by using the formulas given by Acharya and Agarwal (2003).

$\operatorname{PS}(\%)=\frac{\text { PF }}{\text { PC }}$

Where,

PS = Producer's share in consumer's rupee,

$\mathrm{PF}=$ Net price of the produce received by the farmer, and

$\mathrm{PC}=$ Price of the produce paid by the consumer.

The absolute and percentage margin of middlemen involved in marketing was estimated as under:

Absolute margin of $i^{\text {th }}$ middleman $=\mathrm{PR}_{\mathrm{i}}-\left(\mathrm{PP}_{\mathrm{i}}\right.$ $+\mathrm{Cm}_{\mathrm{i}}$ )

$$
\mathrm{PR}_{\mathrm{i}}-\left(\mathrm{PP}_{\mathrm{i}}+\mathrm{Cm}_{\mathrm{i}}\right)
$$

Percentage margin of $i^{\text {th }}$ middleman $=--x 100$

$\mathrm{PR}_{\mathrm{i}}$

Where,

$\mathrm{PR}_{\mathrm{i}}=$ Sale price of the $\mathrm{i}^{\text {th }}$ middleman, 
$\mathrm{PP}_{\mathrm{i}}=$ Purchase price of the $\mathrm{i}^{\text {th }}$ middleman, and

$\mathrm{Cm}_{\mathrm{i}}=$ Cost incurred on marketing by the $\mathrm{i}^{\text {th }}$ middleman.

The total cost incurred on marketing of onion by the farmers and intermediaries involved in the process of marketing was computed as:

$\mathrm{C}=\mathrm{CF}+\mathrm{Cm}_{1}+\mathrm{Cm}_{2}+\ldots \ldots \ldots \ldots . .+\mathrm{Cm}_{\mathrm{n}}$

Where,

$\mathrm{C}=$ Total cost of marketing,

$\mathrm{CF}=$ Cost incurred by the producer in marketing of onion, and

$\mathrm{Cm}_{\mathrm{n}}=$ Cost incurred by the $\mathrm{i}^{\text {th }}$ middleman in marketing onion.

Marketing efficiency was computed by employing the following formula suggested by Acharya and Agarwal (2003).

$\mathrm{MME}=[\mathrm{RP} /(\mathrm{MC}+\mathrm{MM})]-1$

$\mathrm{RP}=\mathrm{FP}+\mathrm{MC}+\mathrm{MM}$

Where,

MME = Modified measure of marketing efficiency,

$\mathrm{RP}=$ Prices paid by the consumer,

$\mathrm{MC}=$ Total marketing costs,

$\mathrm{MM}=$ Net marketing margins,

$\mathrm{FP}=$ Prices received by the farmer.

The Garrett's ranking technique is adopted to analyze the problems faced in the production of onion and its marketing problems. The selected respondent were asked to rank the factors that have limited onion production and also the various marketing problems faced by them. The order of merit given by the respondents was converted into ranks using the following formula separately for both the production and the marketing problems.

Per cent position $=100 \times\left(R_{i j}-0.5\right) / N_{j}$

Where,

$\mathrm{R}_{\mathrm{ij}}=$ Rank given for $\mathrm{i}^{\text {th }}$ factor (constraint) by $\mathrm{j}^{\text {th }}$ individual

$\mathrm{N}_{\mathrm{j}}=$ Number of factors (constraints) ranked by $\mathrm{j}^{\mathrm{th}}$ individual

\section{Results and Discussion}

Considering the perishable nature, bulkiness and seasonal nature of onion, the profitability depends upon how marketing of these vegetable is undertaken by the producers. Therefore, different aspects of marketing viz., disposal pattern, marketable surplus, and agency through whom sold, place of sale, time of sale, marketing costs and margins etc. were analyzed and the results are presented here. Total production, utilization and marketable surplus of onion of different sized farms are presented in Table 1. It is evident from the table that the total production of onion on sampled farms was 59952.50 quintals. Of this on farm utilization was 1.46 per cent. The quantity of onion loss due to damage accounted for 0.45 per cent while the quantity used for relatives for wage purpose and for home consumption was $0.39,0.37$ and 0.25 per cent, respectively. The marketable surplus of onion varied from 94.31 per cent on marginal farms to 99.18 per cent on large farms. As expected, the marketable surplus increased in absolute as well as in percentage terms with the increase in farm size.

Some important factors like agency through whom it is sold, place of sale and time of sale 
influence the net price received by the farmers. The farmer's decisions with respect to agency for sale of onion influenced by number of factors such as mode and transportation facilities available, distance and location of markets, price of the produce, transportation cost, marketable quantity and economic conditions of the farmers. The agency-wise sale of total marketed surplus of onion is presented in Table 2. The total marketable surplus of onion was 59077.62 quintals. Out of this, the major share of 57.89 per cent was sold through commission agent, followed by primary wholesaler $(13.47 \%)$, secondary wholesaler (11.31\%), village merchants $(9.41 \%)$ and retailer $(7.92 \%)$ by sample onion growers. So, details of cost, margin and price spread were studied for all five channels. The maximum quantity sold to commission agent ranged from 58.51 per cent on large farms to 55.04 per cent on marginal size onion farms.

Marketing charges paid by the onion growers for different components are furnished in Table 3. The highest per quintal average total marketing cost of Rs. 57.29 was observed in case of sale of onion through commission agent, followed by (Rs. 51.22) secondary wholesaler, primary wholesaler (Rs. 50.83), village merchants (Rs. 48.09) and retailer (Rs. 43.03) by sample onion growers. Among different components of marketing cost, onion growers incurred the highest proportion of total marketing cost for grading and cleaning followed by the cost incurred for transportation, loading and unloading, damage and other cost, packing charges and weighing cost. The cost of cleaning and grading varied from 32.68 per cent of average total marketing cost in case of commission agents to 36.54 per cent of average total marketing cost in case of village merchants. The cost increased for transportation selected onion grower was the least $(23.87 \%)$ in case of village merchants due to proximity of the distance while the same was the highest in case of commission agent $(25.73 \%)$.

The details about marketing cost incurred by different middleman in the marketing of onion are depicted in Table 4. The table brought to the fore that the highest average total marketing cost per quintal of onion borne by commission agent for (Rs. 98.96) onion, followed by secondary wholesaler (Rs. 89.70), primary wholesaler (Rs. 87.50), retailer (Rs. 75.45) and village merchant (Rs. 63.69). Among the various cost components, transportation cost accounted for about 32.19 per cent of average total marketing cost which was found the highest, followed by cleaning and grading cost (31.62\%), loading and unloading cost (12.56\%), damage/spoilage cost $(9.03 \%)$, other cost $(5.97 \%)$, packing cost (5.50\%), and weighing charges $(3.14 \%)$ in case of village merchants. Among the various cost components of commission agent, transportation cost accounted for about 24.76 per cent of average total marketing cost which was found the highest, followed by cleaning and grading cost $(22.05 \%)$, commission $(15.76 \%)$, loading and unloading cost (11.12\%), damage/spoilage cost $(7.38 \%)$, other cost $(6.57 \%)$, packing cost $(5.15 \%)$, market fee $(3.68 \%)$ and weighing charges (3.54\%).Commission agent incurred the highest marketing cost as compared to other middlemen.

The marketing agency of retailer incurred the highest proportion of 26.24 per cent of average total marketing cost for cleaning and grading followed by transportation cost (25.58\%), commission (17.89\%), loading and unloading cost $(9.28 \%)$, damage/spoilage cost $(7.16 \%)$, market fee $(4.17 \%)$, other cost $(4.11 \%)$, packing cost $(3.31 \%)$ and weighing charges $(2.25 \%)$.

Price spread includes cost of performing various marketing functions and margins of 
different agencies associated in the marketing process of the commodity. The extent of price spread helps policy makers in devising suitable policies for increasing marketing efficiency either by way of reducing the marketing costs or by eliminating unwanted middlemen from the marketing process or by both. The marketing costs, margins and price spread in marketing of onion through all channels have been presented based on the data collected from farmers and market functionaries. The channels identified in the study area were

Channel-I: Producer - Local Merchant Consumer

Channel-II: Producer- Commission agent Primary wholesaler - Retailer - Consumer

Channel-III: Producer - Primary wholesaler Retailer - Consumer

Channel-IV: Producer- Commission agent Primary Wholesaler - Processor

Channel-V: Producer- Primary wholesaler Secondary wholesaler - Processor

On an average, about 54.80, 19.39, 11.10, 9.41 and 5.31 per cent of total onion quantity is moved in the study area through Channel-IV, V, II, I and III, respectively. Thus, more than 54.80 per cent of onion moved through producer to commission agent to primary wholesaler to processor. As such, details of cost, margin and price spread were studied for all channels. The costs incurred and margins earned by various market functionaries as well as price spread in marketing of onion through all Channels are given in Table 5. In ChannelII, the total margin earned by different functionaries was Rs. 103.29 per quintal of onion. It was higher at retailers' level (Rs. 34.55/quintal) compared to commission agents (Rs. 26.24/ quintal) constituting 4.09 per cent and 3.11 per cent of consumer's price, respectively. The highest marketing cost incurred by different functionaries was Rs. 319.00 per quintal of onion, accounting for 37.75 per cent of the consumers' price in Channel-II. Out of total marketing cost, the highest cost (11.69\%) was incurred by commission agent, followed by primary wholesaler $(10.36 \%)$, retailer $(8.93 \%)$ and producer $(6.78 \%)$. Further, it was observed that producer's share was 50.02 per cent of the price paid by onion consumers in Channel-II. The price spread (marketing cost + marketing margins) was 49.98 per cent while the lowest producer's share in consumer's price $(50.02 \%)$ was observed in Channel-II. In Channel-III, the total margin earned by different functionaries was Rs. 107.05 per quintal of onion. It was higher at retailers' level (Rs. 59.55/quintal) compared to primary wholesaler (Rs. 47.50/quintal) constituting 7.54 per cent and 6.01 per cent of consumer's price, respectively.

The total marketing cost incurred by different functionaries was Rs. 213.78 per quintal of onion, accounting 27.06 per cent of the consumers' price. Out of total marketing cost, the highest cost was incurred by primary wholesaler $(11.08 \%)$, followed by retailer $(9.55 \%)$ and producer $(6.43 \%)$. Further, it was observed from the table that producer's share in consumer's price was 59.39 per cent with price spread of 40.61 per cent in Channel-III. In Channel-IV, the total margin earned by different functionaries was Rs. 118.74 per quintal of onion.

It was higher at primary wholesaler level (Rs. 67.50/quintal) compared to commission agent (Rs. 51.24/quintal) constituting 7.80 per cent and 5.92 per cent of consumer's price, respectively. The marketing cost incurred by different functionaries was Rs. 243.55 per quintal of onion, accounting 28.16 per cent of the consumers' price. 
Table.1 Pattern of utilization of onion on the sample farm

\begin{tabular}{|l|l|c|c|c|c|c|c|}
\hline $\begin{array}{l}\text { Sr. } \\
\text { No }\end{array}$ & Particulars & \multicolumn{5}{|c|}{ Farm size } & Total \\
\hline 1. & Total production & Marginal & Small & Medium & Large & \\
& & 2820.00 & 8256.00 & 14932.75 & 33943.75 & 59952.50 \\
& $(100.00)$ & $(100.00)$ & $(100.00)$ & $(100.00)$ & $(100.00)$ \\
\hline & & \multicolumn{3}{|c}{ On farm Utilization } \\
\hline
\end{tabular}

Note: Figure in parenthesis indicate per cent to total production

Table.2 Disposal pattern of onion under different agencies

\begin{tabular}{|l|c|c|c|c|c|}
\hline Marketing agency & \multicolumn{5}{|c|}{ Farm size } \\
\hline Village merchants & 275.27 & 788.12 & 1374.46 & 3121.22 & 5559.07 \\
& $(10.35)$ & $(9.78)$ & $(9.35)$ & $(9.27)$ & $(9.41)$ \\
\hline Primary wholesaler & 413.56 & 1205.84 & 1940.26 & 4395.54 & 7955.20 \\
& $(15.55)$ & $(14.96)$ & $(13.20)$ & $(13.05)$ & $(13.47)$ \\
\hline Secondary wholesaler & 258.50 & 802.42 & 1672.43 & 3948.26 & 6681.61 \\
& $(9.72)$ & $(9.96)$ & $(11.38)$ & $(11.72)$ & $(11.31)$ \\
\hline Commission agent & 1463.86 & 4567.19 & 8473.5 & 19697.70 & 34202.25 \\
& $(55.04)$ & $(56.67)$ & $(57.66)$ & $(58.51)$ & $(57.89)$ \\
\hline Retailer & 248.44 & 695.31 & 1234.24 & 2501.50 & 4679.49 \\
& $(9.34)$ & $(8.63)$ & $(8.39)$ & $(7.43)$ & $(7.92)$ \\
\hline Total Marketable & 2659.63 & 8058.88 & 14694.89 & 33664.22 & 59077.62 \\
\hline Surplus & $(100)$ & $(100)$ & $(100)$ & $(100)$ & $(100)$ \\
\hline
\end{tabular}

Note: Figure in parenthesis indicate per cent to total marketable surplus 
Table.3 Marketing cost incurred by the onion growers

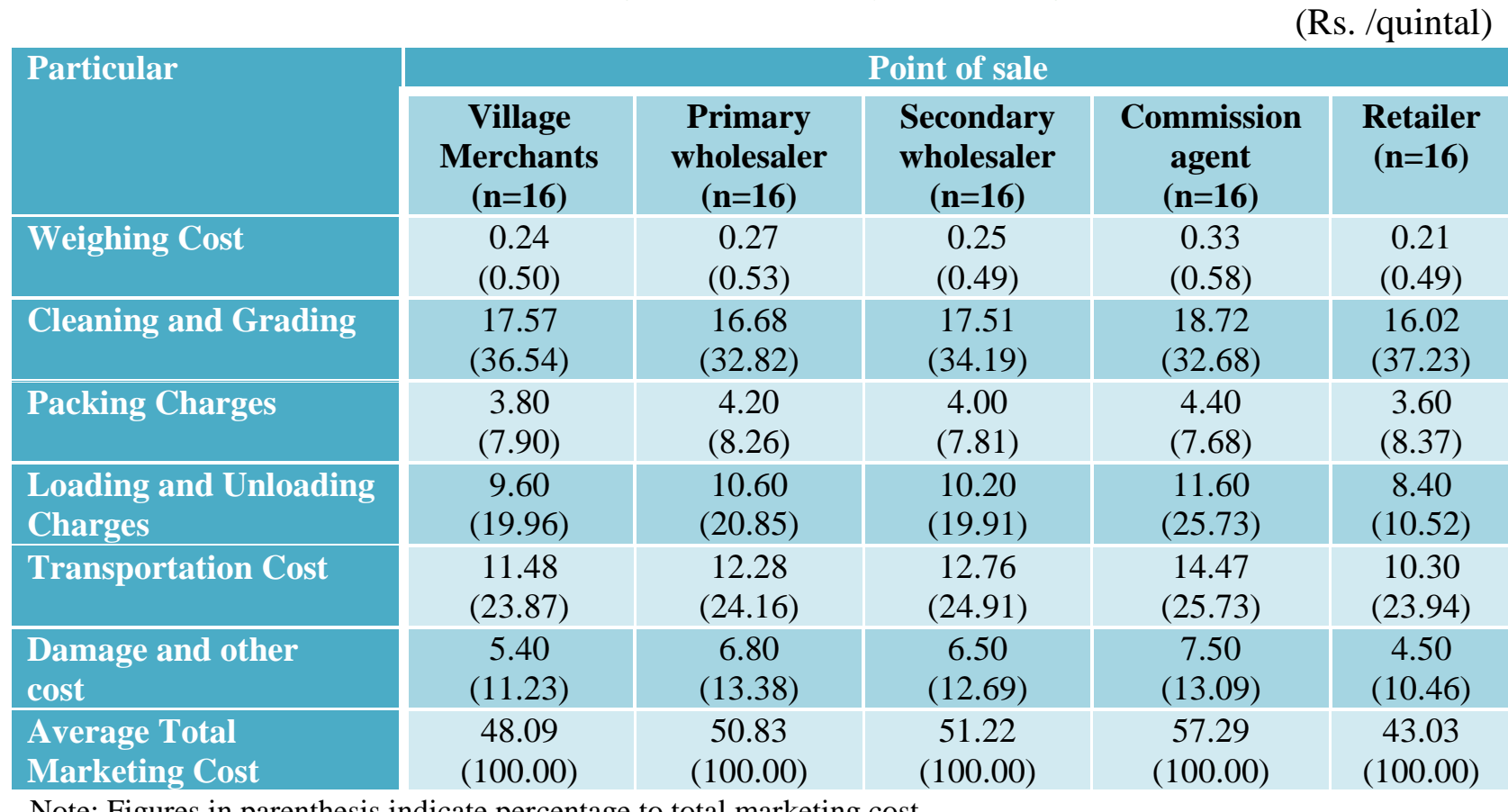

Note: Figures in parenthesis indicate percentage to total marketing cost

Table.4 Marketing cost incurred by different middleman

\begin{tabular}{|c|c|c|c|c|c|}
\hline & & & & & (Rs. /quintal) \\
\hline Particular & $\begin{array}{c}\text { Village } \\
\text { Merchants } \\
(\mathbf{n}=16)\end{array}$ & $\begin{array}{c}\text { Primary } \\
\text { wholesaler } \\
(\mathbf{n}=16)\end{array}$ & $\begin{array}{l}\text { Secondary } \\
\text { wholesaler } \\
(n=16)\end{array}$ & $\begin{array}{c}\text { Commission } \\
\text { agent } \\
(n=16)\end{array}$ & $\begin{array}{c}\text { Retailer } \\
(n=16)\end{array}$ \\
\hline $\begin{array}{l}\text { Cleaning and } \\
\text { Grading }\end{array}$ & $\begin{array}{c}20.14 \\
(31.62)\end{array}$ & $\begin{array}{c}20.82 \\
(23.79)\end{array}$ & $\begin{array}{l}21.03 \\
(23.44)\end{array}$ & $\begin{array}{c}21.82 \\
(22.05)\end{array}$ & $\begin{array}{c}19.80 \\
(26.24)\end{array}$ \\
\hline Weighing Charges & $\begin{array}{c}2.00 \\
(3.14)\end{array}$ & $\begin{array}{c}2.30 \\
(2.63)\end{array}$ & $\begin{array}{c}2.60 \\
(2.90)\end{array}$ & $\begin{array}{c}3.50 \\
(3.54)\end{array}$ & $\begin{array}{c}1.70 \\
(2.25)\end{array}$ \\
\hline Transportation & $\begin{array}{c}20.50 \\
(32.19)\end{array}$ & $\begin{array}{l}21.76 \\
(24.87)\end{array}$ & $\begin{array}{l}22.44 \\
(25.02)\end{array}$ & $\begin{array}{l}24.50 \\
(24.76)\end{array}$ & $\begin{array}{l}19.30 \\
(25.58)\end{array}$ \\
\hline $\begin{array}{l}\text { Loading and } \\
\text { Unloading Charges }\end{array}$ & $\begin{array}{c}8.00 \\
(12.56)\end{array}$ & $\begin{array}{c}9.00 \\
(10.29)\end{array}$ & $\begin{array}{c}9.50 \\
(10.59)\end{array}$ & $\begin{array}{l}11.00 \\
(11.12)\end{array}$ & $\begin{array}{c}7.00 \\
(9.28)\end{array}$ \\
\hline Packing charges & $\begin{array}{c}3.50 \\
(5.50)\end{array}$ & $\begin{array}{c}4.00 \\
(4.57)\end{array}$ & $\begin{array}{c}4.50 \\
(5.02)\end{array}$ & $\begin{array}{c}5.10 \\
(5.15)\end{array}$ & $\begin{array}{c}2.50 \\
(3.31)\end{array}$ \\
\hline Market fee & $\begin{array}{c}0.00 \\
(0.00)\end{array}$ & $\begin{array}{c}3.57 \\
(4.08)\end{array}$ & $\begin{array}{c}3.33 \\
(3.71)\end{array}$ & $\begin{array}{c}3.64 \\
(3.68)\end{array}$ & $\begin{array}{c}3.15 \\
(4.17)\end{array}$ \\
\hline Commission & $\begin{array}{c}0.00 \\
(0.00)\end{array}$ & $\begin{array}{l}15.30 \\
(17.49)\end{array}$ & $\begin{array}{l}14.25 \\
(15.89)\end{array}$ & $\begin{array}{l}15.60 \\
(15.76)\end{array}$ & $\begin{array}{l}13.50 \\
(17.89)\end{array}$ \\
\hline Damage/Spoilage & $\begin{array}{c}5.75 \\
(9.03)\end{array}$ & $\begin{array}{c}6.25 \\
(7.14)\end{array}$ & $\begin{array}{c}6.65 \\
(7.41)\end{array}$ & $\begin{array}{c}7.30 \\
(7.38)\end{array}$ & $\begin{array}{c}5.40 \\
(7.16)\end{array}$ \\
\hline Others & $\begin{array}{c}3.80 \\
(5.97)\end{array}$ & $\begin{array}{c}4.50 \\
(5.14)\end{array}$ & $\begin{array}{c}5.40 \\
(6.02)\end{array}$ & $\begin{array}{c}6.50 \\
(6.57)\end{array}$ & $\begin{array}{c}3.10 \\
(4.11)\end{array}$ \\
\hline $\begin{array}{l}\text { Average Total } \\
\text { Marketing Cost }\end{array}$ & $\begin{array}{c}63.69 \\
(100.00)\end{array}$ & $\begin{array}{c}87.50 \\
(100.00)\end{array}$ & $\begin{array}{c}89.70 \\
(100.00)\end{array}$ & $\begin{array}{c}98.96 \\
(100.00)\end{array}$ & $\begin{array}{c}75.45 \\
(100.00)\end{array}$ \\
\hline
\end{tabular}

Note: Figures in parenthesis indicate percentage to total marketing cost 
Table.5 Cost, margin and price spread in marketing of onion

\begin{tabular}{|c|c|c|c|c|c|c|}
\hline $\begin{array}{l}\text { Sr. } \\
\text { No. }\end{array}$ & Particulars & $\begin{array}{c}\text { Channel } \\
\text {-I }\end{array}$ & $\begin{array}{c}\text { Channel } \\
\text {-II }\end{array}$ & $\begin{array}{l}\text { Channel - } \\
\text { III }\end{array}$ & $\begin{array}{l}\text { Channel } \\
\text {-IV }\end{array}$ & $\begin{array}{c}\text { Channel } \\
-V\end{array}$ \\
\hline 1. & Producer's selling price & 450.00 & 480.00 & 520.00 & 560.00 & 415.00 \\
\hline 2. & Producer's net price & $\begin{array}{l}401.91 \\
(61.83)\end{array}$ & $\begin{array}{l}422.71 \\
(50.02)\end{array}$ & $\begin{array}{l}469.17 \\
(59.39)\end{array}$ & $\begin{array}{l}502.71 \\
(58.12)\end{array}$ & $\begin{array}{l}364.17 \\
(50.58)\end{array}$ \\
\hline \multicolumn{7}{|c|}{ Marketing Cost } \\
\hline \multirow{7}{*}{3.} & (a) Producer & $\begin{array}{l}48.09 \\
(7.40)\end{array}$ & $\begin{array}{l}57.29 \\
(6.78)\end{array}$ & $\begin{array}{l}50.83 \\
(6.43)\end{array}$ & $\begin{array}{l}57.29 \\
(6.62)\end{array}$ & $\begin{array}{l}50.83 \\
(7.06)\end{array}$ \\
\hline & (b) Local merchant & $\begin{array}{l}63.69 \\
(9.80)\end{array}$ & -- & -- & -- & -- \\
\hline & (c) Primary wholesaler & -- & $\begin{array}{c}87.50 \\
(10.36)\end{array}$ & $\begin{array}{c}87.50 \\
(11.08)\end{array}$ & $\begin{array}{c}87.50 \\
(10.12)\end{array}$ & $\begin{array}{c}87.50 \\
(12.15)\end{array}$ \\
\hline & $\begin{array}{l}\text { (d) Secondary } \\
\text { wholesaler }\end{array}$ & -- & -- & -- & -- & $\begin{array}{c}89.70 \\
(12.46)\end{array}$ \\
\hline & (e) Commission agent & -- & $\begin{array}{c}98.76 \\
(11.69)\end{array}$ & -- & $\begin{array}{c}98.76 \\
(11.42)\end{array}$ & -- \\
\hline & (f) Retailer & -- & $\begin{array}{l}75.45 \\
(8.93)\end{array}$ & $\begin{array}{l}75.45 \\
(9.55)\end{array}$ & -- & -- \\
\hline & Total Cost & $\begin{array}{l}111.78 \\
(17.20)\end{array}$ & $\begin{array}{l}319.00 \\
(37.75)\end{array}$ & $\begin{array}{l}213.78 \\
(27.06)\end{array}$ & $\begin{array}{l}243.55 \\
(28.16)\end{array}$ & $\begin{array}{l}228.03 \\
(31.67)\end{array}$ \\
\hline \multicolumn{7}{|c|}{ Marketing Margin } \\
\hline \multirow{6}{*}{4.} & (a) Local merchant & $\begin{array}{l}136.31 \\
(20.97)\end{array}$ & -- & -- & -- & -- \\
\hline & (b) Primary wholesaler & -- & $\begin{array}{l}42.50 \\
(5.03)\end{array}$ & $\begin{array}{l}47.50 \\
(6.01)\end{array}$ & $\begin{array}{l}67.50 \\
(7.80)\end{array}$ & $\begin{array}{c}57.50 \\
(10.76)\end{array}$ \\
\hline & $\begin{array}{l}\text { (c) Secondary } \\
\text { wholesaler }\end{array}$ & -- & -- & -- & -- & $\begin{array}{c}70.30 \\
(12.54)\end{array}$ \\
\hline & (d) Commission agent & -- & $\begin{array}{l}26.24 \\
(3.11)\end{array}$ & -- & $\begin{array}{l}51.24 \\
(5.92)\end{array}$ & -- \\
\hline & (e) Retailer & -- & $\begin{array}{l}34.55 \\
(4.09)\end{array}$ & $\begin{array}{l}59.55 \\
(7.54)\end{array}$ & -- & -- \\
\hline & Total Margins & $\begin{array}{l}136.31 \\
(20.97)\end{array}$ & $\begin{array}{l}103.29 \\
(12.22)\end{array}$ & $\begin{array}{l}107.05 \\
(13.55)\end{array}$ & $\begin{array}{l}118.74 \\
(13.73)\end{array}$ & $\begin{array}{l}127.80 \\
(23.31)\end{array}$ \\
\hline 5. & $\begin{array}{l}\text { Price spread (cost }+ \\
\text { margins) }\end{array}$ & $\begin{array}{l}248.09 \\
(38.17)\end{array}$ & $\begin{array}{l}422.29 \\
(49.98)\end{array}$ & $\begin{array}{l}320.83 \\
(40.61)\end{array}$ & $\begin{array}{l}362.29 \\
(41.88)\end{array}$ & $\begin{array}{l}355.83 \\
(54.98)\end{array}$ \\
\hline 6. & $\begin{array}{l}\text { Consumer's purchase } \\
\text { price }\end{array}$ & $\begin{array}{l}650.00 \\
(100.00)\end{array}$ & $\begin{array}{c}845.00 \\
(100.00)\end{array}$ & $\begin{array}{c}790.00 \\
(100.00)\end{array}$ & $\begin{array}{c}865.00 \\
(100.00)\end{array}$ & $\begin{array}{c}720.00 \\
(100.00)\end{array}$ \\
\hline 7. & $\begin{array}{l}\text { Producer's share in } \\
\text { consumer's rupee (\%) }\end{array}$ & 61.83 & 50.02 & 59.39 & 58.12 & 50.58 \\
\hline
\end{tabular}

Note: Figures in parenthesis indicate percentage to consumer's purchase price 
Table.6 Marketing efficiency of onion

\begin{tabular}{|l|c|c|c|c|c|}
\hline Particulars & $\begin{array}{c}\text { Channel } \\
\text {-I }\end{array}$ & $\begin{array}{c}\text { Channel } \\
\text {-II }\end{array}$ & $\begin{array}{c}\text { Channel } \\
\text {-III }\end{array}$ & $\begin{array}{c}\text { Channel } \\
\text {-IV }\end{array}$ & $\begin{array}{c}\text { Channel } \\
\text {-V }\end{array}$ \\
\hline Consumer's price (Rs./q) & 650.00 & 845.00 & 790.00 & 865.00 & 720.00 \\
\hline Producer's net price (Rs./q) & 401.91 & 422.71 & 469.17 & 502.71 & 364.17 \\
\hline Marketing cost (Rs./q) & 111.78 & 319.00 & 213.78 & 243.55 & 228.03 \\
\hline Marketing margin (Rs./q) & 136.31 & 103.29 & 107.05 & 118.74 & 127.80 \\
\hline Price spread (Rs./q) & 248.09 & 422.29 & 320.83 & 362.29 & 355.83 \\
\hline Marketing efficiency & 1.62 & 1.00 & 1.46 & 1.39 & 1.02 \\
\hline
\end{tabular}

Table.7 Marketing constraints faced by onion growers

\begin{tabular}{|l|l|c|c|c|}
\hline $\begin{array}{l}\text { Sr. } \\
\text { No. }\end{array}$ & A ttributes & $\begin{array}{c}\text { Total } \\
\text { score }\end{array}$ & $\begin{array}{c}\text { Garrett's } \\
\text { score }\end{array}$ & Rank \\
\hline 1. & Lack of transportation facilities & 6408 & 53.40 & 3 \\
\hline 2. & Fluctuation in market prices & 9004 & 75.03 & 1 \\
\hline 3. & Long distance of market & 6113 & 50.94 & 4 \\
\hline 4. & Irregular payment of sale & 3828 & 31.90 & 7 \\
\hline 5. & Lack of storage facilities & 7523 & 62.69 & 2 \\
\hline 6. & Lack of special marketing yard & 5222 & 43.52 & 5 \\
\hline 7. & High spoilage possibilities & 4193 & 34.94 & 6 \\
\hline
\end{tabular}

Out of total marketing cost, the highest cost was incurred by commission agent (11.42\%), followed by primary wholesaler $(10.12 \%)$ and producer $(6.62 \%)$. Further, it was observed from the table that producer's share in consumer's price was 58.12 per cent with 41.88 per cent price spread in Channel-IV. The total margin earned by different functionaries was Rs. 127.80 per quintal of onion in Channel-V. It was higher at secondary wholesaler level (Rs. 70.30/quintal) compared to primary wholesaler (Rs. 57.50/quintal) constituting 12.54 per cent and 10.76 per cent of consumer's price, respectively. The marketing cost incurred by different functionaries was Rs. 228.03 per quintal of onion, accounting 31.67 per cent of the consumers' price. Out of total marketing cost, the highest cost was incurred by secondary wholesaler $(12.46 \%)$, followed by primary wholesaler $(12.15 \%)$ and producer $(7.06 \%)$. The producer's share in consumer's price was 50.58 per cent of the price paid by onion consumers with 54.98 per cent price spread in Channel-V.

Thus, the results of price spread analysis indicated that producers got the highest net price per quintal in the Channel-IV followed by Channel-III, II, I and V. The marketing cost per quintal was the highest in the Channel-II (Rs. 319.00) followed by ChannelIV, V, III and I. It also realized from the data that marketing margin per quintal was the highest in Channel-I (Rs. 136.31) followed by Channel-V, IV, III and II. The producer's share in consumer's rupee per quintal was the highest in Channel-I followed by Channel-III, IV, V and II.

The marketing efficiency for onion has been worked out by considering Acharya's modified formula and the results are presented in Table 6. In case of Channel-I the 
total marketing cost and marketing margins was Rs. 111.78 and Rs. 136.31 per quintal, respectively. While the Consumer's price was Rs. 650.00 per quintal, and the modified marketing efficiency was 1.62. In case of Channel-II, the total marketing cost and marketing margins was Rs. 319.00 and Rs. 103.29 per quintal, respectively.

While the Consumer's price was Rs. 845.00 per quintal, and the modified marketing efficiency was 1.00. In case of different Channel-III, IV, V the total marketing cost and marketing margins was Rs. 213.78, 243.55, 228.03 and Rs. 107.05, 118.74, 127.80 per quintal, respectively. While the Consumer's price was Rs.790.00, 865.00, 720.00 per quintal and the modified marketing efficiency were 1.46, 1.39, and 1.02, respectively. Channel-I is more efficient as compared to other four existing channels in marketing of onion in Bhavnagar district of Gujarat as in this channel producer share in consumer rupees was more $(61.83 \%)$, price spread is relatively less $(38.17 \%)$ with the highest marketing efficiency of 1.62. These results are in conformity with the finding of Patel (2015). They observed that the ChannelI (Producer- Local Merchant - Consumer) was more efficient. They found that the producer share in consumer rupees was 63.36 per cent while the price spread was 36.64 per cent with marketing efficiency of 1.72 in Middle Gujarat.

Marketing constraints faced by onion growers based on the different attributes were assessed and ranked using Garret ranking and the results are presented in Table 7 . The selected farmers revealed that fluctuation in the market price of onion was the main problem expressed with 75.03 Garrett's score by sample farmers (Rank-I). About 62.69 Garrett's score had reported for constraint of lack of storage facilities which were ranked as second constraints while constraints as lack of transportation facilities with a Garrett's score of 53.40, long distance of market with a Garrett's score of 50.94, lack of special marketing yard with a Garrett's score of 43.52, high spoilage possibilities with a Garrett's score of 34.94 and irregular payment of sale with a Garrett's score of 31.90 were other constraints opined by selected onion grower. Similar results were found by Gopala et al., (2012), Khandvi et al., (2013), Vinayak et al., (2013) and Amarnath et al., (2017). They also observed that the fluctuation in market price has been found to be major problem in the marketing of onion grower.

The results of price spread analysis indicated that producers got the highest net price per quintal in the Channel-IV followed by Channel-III, II, I and V. The marketing cost per quintal was the highest in the Channel-II (Rs. 319.00) followed by Channel-IV, V, III and I. While the marketing margin was the highest in Channel-I (Rs. 136.31) followed by Channel-V, IV, III and II. The producer's share in consumer's rupee per quintal was the highest in Channel-I followed by Channel-III, IV, $\mathrm{V}$ and II. The highest marketing efficiency was observed in Channel-I 1.62 followed by Channel-III and IV reported. As regard marketing constraints, majority of the onion cultivators felt the problem of fluctuation in market prices (Rank-I) followed by lack of storage facilities, lack of transportation facilities, long distance of market, lack of special marketing yard, high spoilage possibilities and irregular payment of sale.

Transportation, storage facilities and market information should be made more easily available and accessible to onion growers for better price realization. There is a need to provide market information and also to make provision of logistic support to the onion growers to improve their existing marketing knowledge. Besides, production and 
marketing techniques need to be integrated to reduce the losses.

\section{References}

Acharya, S. S. and Agarwal, N. L. 2003. Agricultural marketing in India. Thirdedition, Oxford and IBH Publishing Corporation, New Delhi. pp 299-336.

Amarnath, J., Velmurugan, S. and Prabakaran K. 2017. Marketing and price forecasting of aggregatum onion in Tamil Nadu. International Journal of Farm Sciences. 7(1): 116-122.

Anonymous. 2017 a. Directorate of Economics and Statistics, Department ofAgricultural, Cooperation and Farmers Welfare, Government of India, New Delhi. Available at http://eands.dacnet.nic.in. Accessed on 31 August, 2017.

Anonymous. 2017 . Directorate of Horticulture, district wise area, production and yield of horticultural crops in Gujarat state. Government of Gujarat, Gandhinagar. http://agri. gujarat.gov.htm. Accessed on: 31 August, 2017.
Ardeshna, N. J. and Shiyani, R. L. 2014. Spatio-temporal growth of garlic and onion crops in Gujarat state. Journal of Spices and Aromatic Crops. 23(1): 120121.

Garett, H. E. and Woodworth, R. S. 1969. Statistics in psychology and education.Vakils, Feffer and Simons Pvt. Ltd., Bombay. p. 329.

Gopala, Y., Yashodhara, B. and Narasimha, N. 2012. Marketing knowledge and problems faced by onion growers of Chitradurga district of Karnataka. Research Journal of Agricultural Sciences. 3(6): 1192-1194.

Khandvi, R. C., Salame, S. P. and Wakle, P. K. 2013. Constraints faced by onion growers with regards to cultivation, storage and market in Buldhana district of Vidarbha region in Maharashtra state. Asian Resonance. 2(4): 105-109.

Patel, V. 2015. An economics analysis of production and marketing of onion in Middle Gujarat. M.Sc. (Agri.) Unpublished Thesis Submitted to the Anand Agricultural University, Anand (Gujarat).

\section{How to cite this article:}

Kantariya, G.K., N.J. Ardeshna, K.M. Vasavada and Thumar, V.M. 2018. Price spread in Different Marketing Channels of Onion in Bhavnagar District of Gujarat, India. Int.J.Curr.Microbiol.App.Sci. 7(10): 307-317. doi: https://doi.org/10.20546/ijcmas.2018.710.032 